\title{
Diasporic Connections: Cahokia and the Greater Southeast
}

\author{
Melissa R. Baltus ${ }^{1} \cdot$ Sarah E. Baires $^{2}$ • Elizabeth Watts Malouchos ${ }^{3}$. \\ Jayur Madhusudan Mehta ${ }^{4}$
}

Published online: 12 February 2020

(C) Springer Science+Business Media, LLC, part of Springer Nature 2020

The rise of Cahokia, the largest pre-Columbian Native American city north of Mexico, and the rapid spread of Mississippian culture across the midcontinental and southeastern USA after AD 1000 has long been a focus of archaeological inquiry. Trade, political control, and emulation constitute some of the theories used to examine the wide distribution of Cahokian artifacts and architecture. Early cultural historical interpretations focused on migration and diffusion as the mechanism by which Cahokian objects and practices spread, a position heavily critiqued by processualists. Mounting archaeological evidence, now supported by technological advancements in materials-sourcing and isotope analyses (see Emerson and Hedman 2016; Slater et al. 2014), has brought back theories of migration, with attendant processes of hybridity and creolization (see Alt 2006, 2018; Millhouse 2012), to characterize Mississippian interactions and movements. These movements highlight the diverse cultural interactions that worked to, in part, create this Native American city-one that informed the spread of Mississippianism beyond the American Bottom.

For this special issue, we invited our colleagues to consider the possibility and role of a Cahokian diaspora to understand cultural influence, complexity, historicity, and movements in the Mississippian Southeast. Collectively, we trace how the movements of Cahokian and American Bottom materials, substances, persons, and non-human bodies converged in the creation of Cahokian identities both within and outside of the Cahokia homeland. Drawing initial inspiration from theories of diaspora, our goal in organizing this collection of papers was to explore the dynamic movements of human populations by critically engaging with the ways people materially construct or deconstruct their social identities in relation to others within the context of physical movement.

Melissa R. Baltus

melissa.baltus@utoledo.edu

1 Department of Sociology and Anthropology, University of Toledo, Toledo, OH 43606, USA

2 Eastern Connecticut State University, Willimantic, Windham, CT 06226, USA

3 Glenn A. Black Laboratory of Archaeology, Indiana University, Bloomington, IN 47408, USA

4 Florida State University, Tallahassee, FL 32306, USA 
While theories of diaspora have become multiple and varied, the central tenets remain the same: population dispersion, reference to (or nostalgia for (Buchanan 2020)) a homeland, and maintenance of identities that are at variance with those of the "host" population (Brubaker 2006; Cipolla 2017; Clifford 1994; Cohen 1997; Lilley 2006; Safran 1991). The contributions to this special issue engage with diaspora to understand Mississippian population movements and explore components of Cahokian identity created, preserved, and maintained outside of the American Bottom "homeland" through archaeological case studies that demonstrate the ways in which population movements foment social change. Research representing multiple sites, time periods, and cultures spanning the Mississippian world highlighted the intersections between materiality, memory, place-making, and person-making to address the centrifugal and centripetal forces tied to this unique and monumental place. These papers engage with diaspora in disparate ways through considerations of movements of people and goods to and from Cahokia, which include conversations about diaspora as entangled with cosmology and ties to a "place-as-idea." Here we provide a brief summary of the papers that follow while highlighting the ways diaspora theory contributes to our understanding of Cahokia's emergence and the translation of Mississippian ideals into the Greater Southeast.

\section{Diasporic Connections}

Ashley and Thunen (2020) examine diaspora through connections among persons, place, and the seeking and exchange of knowledge. Perhaps their greatest contribution to the conversation on Cahokia Diaspora is their recognition that people travel long distances not solely to trade or to migrate but also to seek knowledge unique to that disparate place and to perhaps share their own with the people they encounter. Their article examines the possibility of long-distance travelers from Cahokia bringing with them materials steeped in esoteric knowledge to St. Johns people in Florida, but what this article does best is create a vivid imaginary of how these Cahokian travelers might have experienced the "edge of the world" - the Atlantic Ocean. When thinking about diaspora, Ashley and Thunen remind us that diaspora is not a fixed place, but experience entangled with the exchange of knowledge.

Mehta and Connaway (2020) explore potential southern ties with Cahokia in the Yazoo Basin through the lens of a trade diaspora. This concept is drawn from historical references to enclaves of specialized merchant groups who maintain a distinct identity separate from a "host" society. The motivations in a trade diaspora are based on exchange, though Mehta and Connaway suggest for the Carson site specifically, trade may have been a bi-product of a more complex movement of people returning to an ancestral homeland or a "heritage diaspora."

The political-economic view of Mehta and Connaway juxtaposes with Emerson et al.'s (2020) relational perspective on the movement of people, landscape, and "homeland." They highlight the variability of motivations for why people move across a landscape as well as the diversity of processes through which materials and things wind up in regions outside Cahokia. In tackling the concept of diaspora, Emerson and colleagues argue that we need to better understand the complexities of a "homeland" and an originating population in order to understand those motivations and processes of movement. 
Buchanan's (2020) contribution to this issue challenges the utility of a "checklist" approach to identifying diasporic populations in the past (and arguably the present); instead, she highlights the concept of nostalgia in processes of population movement. Specifically considering the out-migration of Cahokians during a period of regional violence during the thirteenth to fourteenth centuries, Buchanan describes the phenomenological experience of relocation as a means of mediating past-present-future relations through nostalgic materialities.

Similarly, Wilson et al. (2020) critique the lack of explication that the various typologies of diaspora offer, arguing that the concept of diaspora alone will likely not produce any new explanatory models for Cahokia without a deeper consideration of "different modes of living" and changes in such over time. Using the Central Illinois River Valley (CIRV) as a case study, they offer a diachronic view of population movements between the American Bottom and the CIRV. By decentering Cahokia in the discussion of migrations and movements, they demonstrate long-term persistence of local traditions alongside Cahokian Mississippian and hybrid practices. This persistence highlights the importance of agency and individual choice in making and foregrounding local ties versus distant social connections.

Complementary to Emerson et al. (2020), Baltus and Baires (2020) focus on Cahokia as a Place of Origin and a referential "homeland" where Cahokia's impact across the greater southeast can be traced through the movements of people and their ties to "home." From this perspective, Baltus and Baires consider the implications of this Central Place or Place of Origin in the context of abandonment to examine the choices people make when they leave. What practices are "carried away" and what practices are abandoned altogether, and how does this process of dissolution, then, create Cahokia as a Place of Origin? Baltus and Baires argue that similarity in material goods alone does not make a diaspora and if assumed as such can lead to the attachment of static cultural meanings to people and materials. Instead, they argue for a self-reflexive process of analysis to consider diaspora as a plurality of persons (human and otherwise) where local histories may be the most appropriate lens through which to examine the subtle cultural references to Cahokia as a Place of Origin.

Watts Malouchos' (2020) contribution likewise applies a broadly inclusive definition of diaspora, focusing on the movement of people and an idea of "homeland," while offering a sound critique of the third criteria: maintenance of social boundaries. Demonstrating the problematic nature of a "static" identity that such boundary maintenance suggests, Watts Malouchos considers Cahokian connections in the Ohio River Valley near the site of Angel Mounds. More so than physical objects like stone tools and pottery, Watts Malouchos shows how landscape and architecture reference and physically reinforce ties to Cahokia through people's experience of living and moving within that landscape. These references may connect Angel with Cahokia as a physical homeland for some, or perhaps as a cosmological origin point, while at the same time facilitating the negotiation of local identities.

\section{Conclusion}

Critiques leveled against diaspora theory include the overly broad proliferation of diaspora as descriptive lens (Brubaker 2005), defining criteria of diaspora as little more 
than a list of traits, and a lack of problematizing how boundaries and identity become reified through the lens of diaspora (see Cipolla 2017). This group of papers is diverse, but each reinforces the idea that we must be wary of trait lists and instead examine the archeological record through a consideration of processes and interactions where materials are one piece of the proverbial puzzle. What unites each of the papers in this issue are the author's struggles with diaspora-how to define it, use it, and make it meaningful in a pre-modern context. While the basic premise of what a diaspora "is" is shared (e.g., communities living outside a recognized homeland), each case study focuses on this concept differently, through examinations of creation of place, material exchange, movement of people, and political or religious connections between communities. This collection demonstrates that a strict focus on diaspora was perhaps too simplistic to encapsulate the diversity of social processes that resulted in Cahokian objects, persons, and practices dispersed throughout the midcontinent and southeast.

Rather than considering diaspora as a specific blanket theory to understand the appearance of Cahokian objects and practices outside of the American Bottom, we suggest the diasporic lens is more broadly useful as a means of engaging the process of homeland creation and imagining. By focusing on this aspect of the diaspora "criteria" - the idea of an ancestral homeland - we can problematize and reconsider the diversity notable in the dispersal of bodies (human and otherwise) outside of the American Bottom. This creation of a homeland to which identities are attached need not require a physical origination, but rather a construction of an imagined origin point of a people united by a centering Place. Through this Origin Place creation, Cahokia had reverberations across the midcontinent, archaeologically visible as unique objects and practices which reference Cahokia in various ways - architectural alignments that cite Cahokian cosmography (Watts Malouchos 2020), ear ornaments that mimic those of a narrative hero, figural carvings, and embossed copper plates (Pauketat 2004). Given the origin of Cahokia in movement and the convergence of human and material bodies, perhaps the circulation of these bodies - along with the human bodies with whom they traveled - are a continuation of the processes by which Cahokia emerged.

Additionally, we question whether we should expect continued "boundary maintenance" between former Cahokians and their new communities in all instances. At parts of Cahokia, rapid transformations to house style and homogenization of pottery assemblages indicate adoption of a local Cahokian identity. Simultaneously, additional evidence at sites peripheral to Cahokia suggests some participants did not "lose" their material identities but rather continued their traditional settlement practices and foodways until they dispersed from the region (Alt 2002; 2006). This does not mean they were unchanged from their time near Cahokia, but perhaps those transformations they take away with them will not be visible to us in the ways we expect (pottery, house style). The negotiation of identity and practice is complicated and locally variable, and we should expect the same variability outside of Cahokia.

As a final note, we wish to acknowledge the debt this work owes to Charles McNutt and Ryan Parish, and their Mid-South Archaeological Conference in 2016, which focused on Cahokian connections and influence across the Mississippian world. With their blessings, we pursued research and publication of these papers as an additional investigation explicitly within the frameworks of diaspora theory. McNutt and Parish's edited volume from the Mid-South meetings, Cahokia in Context: Hegemony and Diaspora (McNutt and Parish 2020), exists as an ancestor and cousin to these papers, 
and as a whole, both consider the myriads of ways in which corn farmers in the Midwest produced a sphere of influence spanning from Wisconsin to Louisiana, and from Oklahoma to Florida. These sets of papers will not be the final consideration of these topics as science is never settled and we hope that future excavations and research shine a brighter light on how humans migrate and why they carry with them what they choose to carry.

We hope the broader anthropological implications of these works help to frame processes of migration and identity during an era of deeply contentious American geopolitics. Mass human migrations as a result of war have characterized the second decade of the twenty-first century, and we can only expect more migrant and refugee crises as sea levels continue to climb an additional meter to meter and a half by AD 2100 (IPCC 2019). With 40\% of the world's population living within $100 \mathrm{~km}$ of coastal zones, we must expect significant social challenges as mass human migrations seek relief from rising oceans, rapid-onset and destructive storms, and slow-onset disasters like drought and famine. In light of these migrations, issues of diaspora, identity, and culture conflict will remain salient in the public eye. We hope that they, the general public, lawmakers, and scholars across various disciplines, will look to archaeology and the social sciences for insights into how human societies have grappled with the challenges of accepting outsiders, welcoming refugees, and navigating unequal power relationships across contested borders. These papers, like those in the McNutt and Parish volume, grapple with understanding migration, power, and identity, and diaspora as a concept more broadly, and we hope they can serve as lessons, lenses, or heuristics through which we can better understand the present as well as future social issues.

\section{References}

Alt, S.M. (2006) The Power of Diversity: The Roles of Migration and Hybridity in Culture Change. In Leadership and Polity in Mississippian Society, edited by B.M. Butler and P.D. Welch, pp. 289-308. Center for Archaeological Investigations Occasional Paper No. 33. Southern Illinois University Carbondale.

Alt, S.M. (2018) Cahokia's Complexities: Ceremonies and politics of the first Mississippian farmers. Tuscaloosa: The University of Alabama Press.

Alt, S. M. (2002). Identities, traditions and diversity in Cahokia's uplands. Midcontinental Journal of Archaeology, 27, 217-236.

Ashley, K. and R.L. Thunen (2020). St. Johns river fisher-hunter-gatherers: Florida's connection to Cahokia. Journal of Archaeological Method and Theory, 27(1).

Baltus, M.R. and S.E. Baires (2020) Defining diaspora: a view from the Cahokia homeland. Journal of Archaeological Method and Theory, 27(1).

Brubaker, R. (2005). The 'diaspora' diaspora. Ethnic and Racial Studies, 28(1), 1-19.

Buchanan, M. E. (2020). Diasporic longings? Cahokia, common field, and nostalgic orientations. Journal of Archaeological Method and Theory, 27(1), 1-18. https://doi.org/10.1007/s10816-019-09431-z.

Cipolla, C. N. (2017). Native American diaspora and ethnogenesis. Oxford Online.

Clifford, J. (1994). Diasporas. Cultural Anthropology, 9(3), 302-338.

Cohen, R. (1997). Global diasporas: an introduction. London: UCL Press.

Emerson, T. E., and K. M. Hedman (2016) The dangers of diversity: the consolidation and dissolution of Cahokia, native North America's first urban polity. In Beyond collapse: archaeological perspectives on resilience, revitalization, and transformation in complex societies, edited by Ronald K. Faulseit, pp. 147175. Center for Archaeological Investigations, Occasional Paper No. 42. Southern Illinois University Press, Carbondale. 
Emerson, T.E., K.M. Hedman, T.K. Brennan, A.M. Betzenhauser, S.M. Alt, and T.R. Pauketat (2020). Interrogating diaspora and movement in the greater Cahokian world. Journal of Archaeological Method and Theory, 27(1).

IPCC (2019) Summary for policymakers. In: IPCC Special report on the ocean and cryosphere in a changing climate [H.O. Pörtner, D.C. Roberts, V. Masson-Delmotte, P. Zhai, M. Tignor, E. Poloczanska, K. Mintenbeck, M. Nicolai, A. Okem, J. Petzold, B. Rama, N. Weyer (eds.)]. In press.

Lilley, I. (2006). Archaeology, diaspora and decolonization. Journal of Social Archaeology, 6(1), $28-47$.

McNutt, C. H., \& Parish, R. M. (2020). Cahokia in context: hegemony and diaspora. Gainesville: University Press of Florida.

Mehta, J. M., \& Connaway, J. M. (2020). Mississippian culture and Cahokian identities as considered through household archaeology at Carson, a monumental center in North Mississippi. Journal of Archaeological Method and Theory, 27(1).

Millhouse, P. (2012) The John Chapman site and creolization on the northern frontier of the Mississippian world. Ph.D. Dissertation, Department of Anthropology, University of Illinois at Urbana-Champaign.

Pauketat, T. R. (2004). Ancient Cahokia and the Mississippians. New York: Cambridge University Press.

Safran, W. (1991). Diasporas in modern societies: myths of homeland and return. Diaspora, 1, 83-99.

Slater, P. A., Hedman, K. M., \& Emerson, T. E. (2014). Immigrants at the Mississippian polity of Cahokia: strontium isotope evidence for population movement. Journal of Archaeological Science, 44, 117-127.

Watts Malouchos, E. L. (2020). Angel ethnogenesis and the Cahokian diaspora. Journal of Archaeological Method and Theory, 27(1).

Wilson, G. D., Bardolph, D. N., Esarey, D., \& Wilson, J. J. (2020). Early Mississippian diasporas of the north American midcontinent. Journal of Archaeological Method and Theory, 27(1).

Publisher's Note Springer Nature remains neutral with regard to jurisdictional claims in published maps and institutional affiliations. 